\title{
Comparative Evaluation of Antimicrobial Efficacy of Neem, Miswak, Propolis, and Sodium Hypochlorite against Enterococcus faecalis using EndoVac
}

\author{
${ }^{1}$ Priya Daga, ${ }^{2}$ Hemant Asrani, ${ }^{3}$ Shanin Farista, ${ }^{4}$ Praveen Mishra
}

\begin{abstract}
Aim: To compare the antimicrobial efficacy of herbal irrigants neem, miswak, propolis with sodium hypochlorite using conventional needle irrigation and EndoVac irrigation system against Enterococcus faecalis.
\end{abstract}

Materials and methods: A total of 120 extracted single-rooted mandibular premolar teeth were infected for 21 days with E. faecalis after instrumentation with ProTaper system. Before irrigation procedure, dentinal shavings were collected in $1 \mathrm{~mL}$ of sterile broth and incubated. The optical density of each broth was measured using digital colorimeter and initial readings were recorded. Samples were then divided into four groups of 30 teeth each - Group I: Sodium hypochlorite irrigation, group II: Neem irrigation, group III: Miswak irrigation, group IV: propolis irrigation. Each group was further divided into two subgroups - (a) EndoVac irrigation (b) conventional needle irrigation. After irrigation, dentinal shavings were collected and optical density recorded. The values were analyzed statistically with Student's t test and analysis of variance followed by Tukey's honest significant difference test; $p$-value $<0.05$ was considered to be statistically significant.

Results: The postirrigation optical densities in all the groups were significantly lower than preirrigation values. Sodium hypochlorite demonstrated better antimicrobial efficacy followed by propolis, neem, and miswak. Differences in optical density values for all irrigants are higher in EndoVac $(p<0.0001)$ compared with needle $(p=0.0009)$ group, but it failed to reach statistical significance.

Conclusion: Sodium hypochlorite proved to be a better irrigant followed by propolis, neem, and miswak. EndoVac irrigation system was more effective for elimination of $E$. faecalis than needle irrigation group.

Keywords: Enterococcus faecalis, EndoVac, Miswak, Neem, Propolis, Sodium hypochlorite.

How to cite this article: Daga P, Asrani H, Farista S, Mishra P. Comparative Evaluation of Antimicrobial Efficacy of Neem, Miswak, Propolis, and Sodium Hypochlorite against Enterococcus faecalis using EndoVac. Int J Prosthodont Restor Dent 2017;7(2):60-65.

\footnotetext{
${ }^{1,3,4}$ Postgraduate Student, ${ }^{2}$ Professor and Head

${ }^{1-4}$ Department of Conservative Dentistry and Endodontics, Maitri College of Dentistry \& Research Centre, Durg, Chhattisgarh India

Corresponding Author: Priya Daga, Postgraduate Student Department of Conservative Dentistry and Endodontics, Maitri College of Dentistry \& Research Centre, Durg, Chhattisgarh India, Phone: +918871274871, e-mail: drpriyadaga@gmail.com
}

Source of support: Nil

Conflict of interest: None

\section{INTRODUCTION}

Elimination or evidential reduction of irritants and prevention of reinfection of the root canal after treatment are the key requisites for successful outcomes. Infections in endodontics are polymicrobial in nature, but it is dominated by obligate anaerobic bacteria. ${ }^{1}$ The etiology of periradicular lesions after root canal treatment is the persistence of Enterococcus faecalis (24-77\% cases). ${ }^{2}$ This bacterium may survive in the root canal as a single microbe or as a major component of the flora.

Microbial load of root canal system can be decreased by mechanical preparation of the root canal and disinfection. Irrigation is adjunctive to instrumentation in aiding the removal of pulp tissue and/or microorganisms. Sodium hypochlorite is a well-known root canal irrigation solution for its antimicrobial ${ }^{3,4}$ and organic tissue-dissolving abilities. ${ }^{5}$ But certain drawbacks like its unpleasant taste and periapical tissue irritation potential have impelled researchers to find other substitutes. The perpetual rise in antibiotic resistant strains and adverse effects of synthetic irrigants have led to the search for herbal alternatives. ${ }^{6}$

Herbal products are researched as they naturally possess antimicrobial, anti-inflammatory, and antioxidant properties alongside its biocompatibility. Other advantages are its easy availability, safety, cost-effectiveness, and long shelf life. Many herbal products have been studied in vitro for their use as irrigant like neem, miswak, propolis, tea tree oil, triphala, noni, turmeric, green tea extract, etc. In the present study, neem, miswak, and propolis are used as these are suggested to have desirable properties of root canal irrigant comparable with that of sodium hypochlorite.

Azadirachta indica (Neem) is the most commercially exploited traditional and medicinal plant of India. Use of neem as an endodontic irrigant might be advantageous because it is biocompatible, antimicrobial, antiadherent, and antioxidant. ${ }^{2,7}$

Salvadora persica (Miswak) chewing sticks are a popular oral hygiene aid and have numerous biological properties. 
Its antimicrobial and cleaning effects are attributed to various chemicals detected like cyanogenic glycoside and benzyl-isothiocyanate as well as high content of $\mathrm{NaCl}$ and $\mathrm{KCl}$, salvadourea, salvadorine, saponins, tannins, vitamin C, silica, and resin. ${ }^{1}$

Propolis (bee glue) is a resinous brown material collected by bees chiefly from plants like poplar and coniferous trees or clusia flowers. Flavonoids, the main constituent of propolis, are the active ingredient, with most of its properties like antioxidant, antimicrobial, anticancer, and anti-inflammatory. ${ }^{8-10}$ Recently, it has drawn much attention in endodontics for its use as an intracanal irrigant and medicament.

To improve root canal disinfection, the aspiration/ irrigation EndoVac system (SybronEndo, Orange, CA, USA) is used that delivers irrigant to the entire working length (WL) of the canal. ${ }^{11,12}$ It is based on negative pressure for irrigation which creates a flow strong enough to flush out debris yet avoiding the risk of injury due to overflow of the irrigant to periapical tissues. ${ }^{13,14}$ The system consists of a master delivery tip (MDT), a macrocannula, and a microcannula, which allow the delivery and evacuation of the irrigating solution concomitantly.

Thus, the purpose of this study is to compare the antimicrobial efficacy of herbal irrigants, namely neem, miswak, propolis, with the commonly used irrigant sodium hypochlorite using conventional needle irrigation and EndoVac irrigation system against E. faecalis.

\section{MATERIALS AND METHODS}

\section{Teeth Selection and Preparation}

A total of 120 extracted human single rooted mandibular premolar teeth with patent root canals and fully developed root apices, extracted for periodontal or orthodontic reason, were selected for the study. Teeth having cervical caries, cracks in root, immature apex, resorbed roots, and calcified canals were excluded. Each tooth was radiographed buccolingually and mesiodistally to confirm the presence of a single patent canal and sectioned below the cementoenamel junction with a diamond disk to obtain a standardized root length of $13 \mathrm{~mm}$. Canal patency was established using $10 \mathrm{~K}$ file and instrumented using ProTaper Universal rotary file system (Dentsply Maillefer, Ballaigues, Switzerland) up to an apical size of file F4. A total of $2 \mathrm{~mL}$ of $3 \% \mathrm{NaOCl}$ was used between each instrument during the procedure, followed by irrigation with $17 \%$ ethylenediaminetetraacetic acid for 1 minute to remove the smear layer.

A customized model was assembled for each tooth for succeeding procedures. Apical third of tooth was covered with two coats of nail varnish. The teeth were embedded in polyvinyl siloxane impression material up to their standardized length. The customized models of teeth were steam autoclaved at $121^{\circ} \mathrm{C}, 15$ psi for 15 minutes.

\section{Contamination of Specimen}

Enterococcus faecalis American Type Culture Collection 29212 (HiMedia Laboratories Pvt. Ltd., Mumbai, India) was taken from $4^{\circ} \mathrm{C}$ stock culture and streaked out on Mueller-Hinton agar, incubated for 48 hours at $37^{\circ} \mathrm{C}$. A suspension was prepared by inoculating E. faecalis from pure culture into Brain Heart Infusion (BHI) broth, incubated at $37^{\circ} \mathrm{C}$ for 24 hours, and adjusted to an optical density of 1 with sterile BHI broth. Each root canal was completely filled with the infected broth by using sterile $1 \mathrm{~mL}$ insulin syringes. Histological slides were prepared with Gram's stains to confirm the presence of bacteria (Fig. 1). Samples were divided into four groups of 15 teeth each, placed inside a plastic box and incubated at $37^{\circ} \mathrm{C}$ for 21 days. After the initial, fresh broth was added to the canal every 48 hours. After 21 days, saline irrigation was done to eliminate the broth from the canals. Dentin was collected with Gates Glidden drill No. 3 and dentinal shavings transferred using absorbent paper point into $1 \mathrm{~mL}$ of broth in test tubes for each specimen and incubated for 24 hours at $37^{\circ} \mathrm{C}$. The optical density of the broth was measured using digital colorimeter (Fig. 2) and initial readings were recorded. All the procedures were carried out in laminar air flow chamber.

\section{Preparation of Neem Irrigating Solution}

Fresh $A$. indica leaves were collected, washed using distilled water, and weighed; 25 gm of fresh neem leaves was added to $50 \mathrm{~mL}$ of absolute ethanol and macerated for 1 to 2 minutes. Mixture was filtered for coarse residue using muslin cloth. This process was repeated again for coarse residue with $25 \mathrm{~mL}$ ethanol. These two extracts

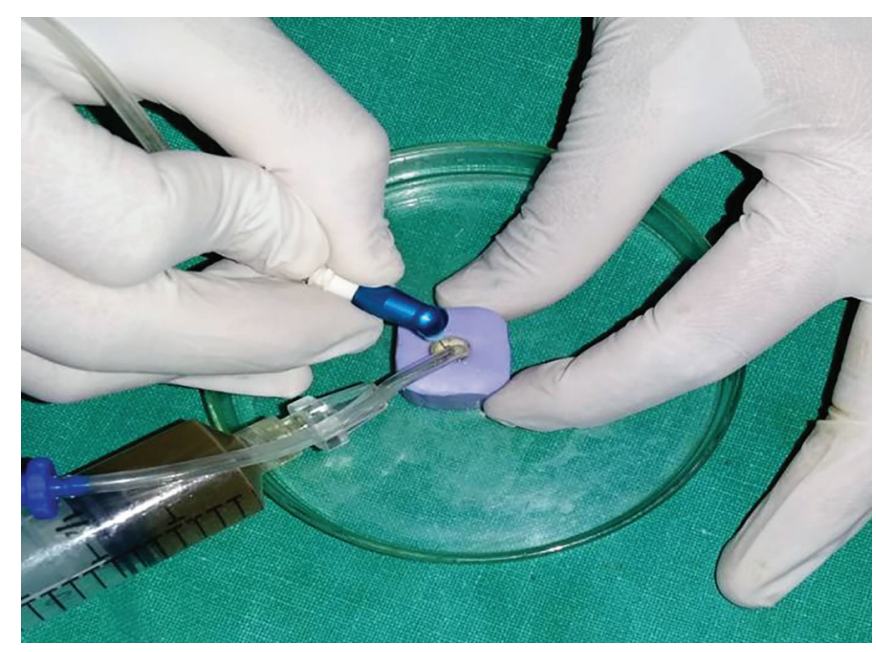

Fig. 1: Microscopic view showing gram-stained E. faecalis colonies 


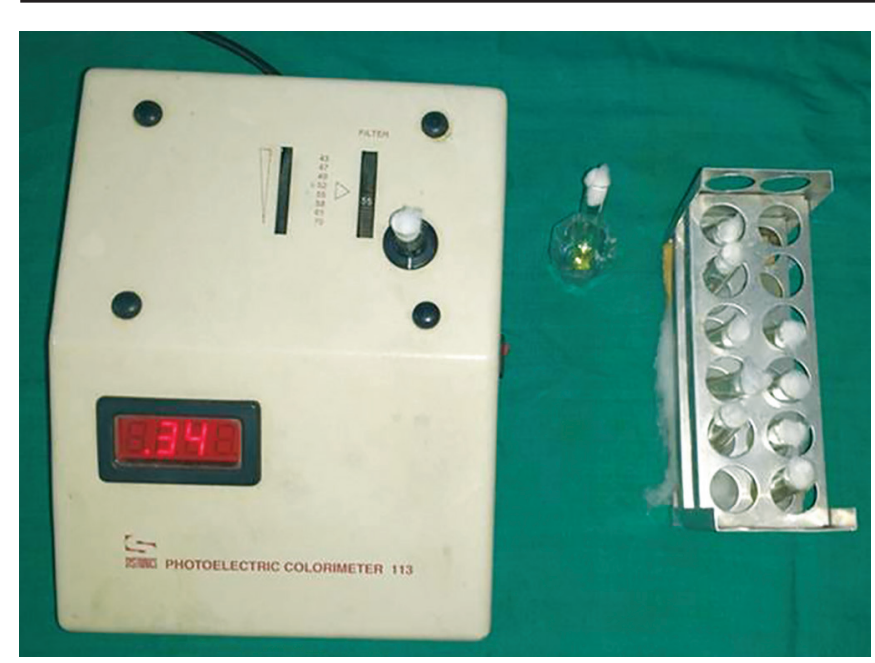

Fig. 2: Colorimeter showing reading of $\mathrm{BHI}$ broth with E. faecalis growth after overnight incubation

were pooled together and filtered using fast filter paper. To remove the alcohol part, the extract was placed on water bath until it reduced to $25 \mathrm{~mL}$ solution. This solution was kept ready and stored in airtight amber-colored container.

\section{Preparation of Miswak Irrigating Solution}

A total of $800 \mathrm{gm}$ of S. persica (Alhuda Impex, Karachi, Pakistan) chewing sticks were ground to powder using food blender; $40 \mathrm{gm}$ of powder was added to $120 \mathrm{~mL}$ of $60 \%$ ethanol in a sterile well-capped bottle, left at room temperature for 3 days, and filtered with fast filter paper. The extract was incubated at $37^{\circ} \mathrm{C}$ until it became dry and refrigerated in sterile screw-capped vials until needed. To make $12.5 \%$ of miswak solution, $1 \mathrm{gm}$ of dried extract was dissolved in $2.5 \mathrm{~mL}$ of Ringer's lactate (RL) to give $100 \%$ concentration. Respectively, $50 \%$ (2.5 mL of $100 \%$ extract $+2.5 \mathrm{~mL} \mathrm{RL}), 25 \%$ ( $2.5 \mathrm{~mL}$ of $50 \%$ extract $+2.5 \mathrm{~mL}$ $\mathrm{RL})$, and $12.5 \%$ ( $2.5 \mathrm{~mL}$ of $50 \%$ extract $+2.5 \mathrm{~mL} \mathrm{RL})$ were obtained. This $12.5 \%$ alcoholic concentration of miswak was used for the study.

\section{Preparation of Propolis Irrigating Solution}

About $11 \%$ alcoholic extract was made by diluting commercially available $33 \%$ concentration of propolis (Hi-Tech Natural Products India Ltd., Delhi, India) using warm saline in 2:1 ratio (by volume).

\section{Irrigation of the Specimens}

All the teeth were then subjected to irrigation under following groups:

- Group I: Irrigation with sodium hypochlorite solution $(\mathrm{n}=30)$

- Subgroup A: EndoVac irrigation $(\mathrm{n}=15)$

- Subgroup B: Conventional needle irrigation $(\mathrm{n}=15)$

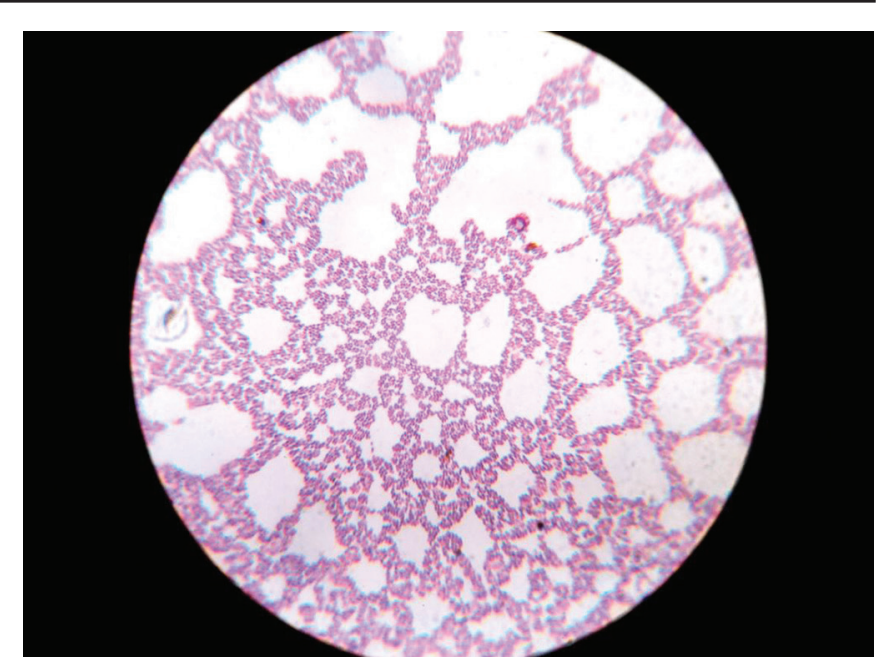

Fig. 3: Irrigation using EndoVac system

- Group II: Irrigation with neem solution $(\mathrm{n}=30)$

- Subgroup A: EndoVac irrigation $(\mathrm{n}=15)$

- Subgroup B: Conventional needle irrigation $(\mathrm{n}=15)$

- Group III: Irrigation with miswak solution $(\mathrm{n}=30)$

- Subgroup A: EndoVac irrigation $(\mathrm{n}=15)$

- Subgroup B: Conventional needle irrigation $(\mathrm{n}=15)$

- Group IV: Irrigation with propolis solution $(\mathrm{n}=30)$

- Subgroup A: EndoVac irrigation $(\mathrm{n}=15)$

- Subgroup B: Conventional needle irrigation $(\mathrm{n}=15)$

\section{Endovac Irrigation}

EndoVac system was used as per manufacturer's recommendations (Fig. 3). First macroirrigation of each canal was accomplished for 30 seconds using the MDT, while the macrocannula was moved up and down constantly within the prepared canal. The canal space was then left full of irrigant and undisturbed for 60 seconds. Following this, three cycles of microirrigation was done, wherein the pulp chamber was kept full of irrigant with the microcannula placed at the WL for 6 seconds, then $2 \mathrm{~mm}$ from WL for 6 seconds, and again at the WL for 6 seconds. This up-down motion continued until 30 seconds, so that 18 seconds of active irrigation occurs directly at the WL. Following this, the microcannula was withdrawn from the canal in the presence of enough irrigant in the pulp chamber so as to ensure that no air was drawn into the canal space and the canal remained totally filled with irrigant. This was left undisturbed for 60 seconds. This completed one microirrigation cycle. At the end of the third microirrigation cycle, excess irrigant was removed from canal by leaving microcannula at the WL without replenishment.

\section{Conventional Needle Irrigation}

Irrigation with 30 gauge side-vented needle was performed by constant up-down motion of needle from 
2 to $4 \mathrm{~mm}$ from the WL for 30 seconds. Irrigant was left in the canal for 60 seconds. The excess irrigant was removed from the canal by using absorbent paper points.

In all the groups, $10 \mathrm{~mL}$ of irrigating solution was used for each tooth. After irrigation procedure, dentinal shavings were collected from root canal of each tooth as previously mentioned and incubated for 24 hours at $37^{\circ} \mathrm{C}$. The optical density of the broth was measured using digital colorimeter (Fig. 2) and postirrigation readings were recorded.

\section{Statistical Analysis}

Data was expressed as mean \pm standard deviation (SD). Student's t-test was used to study significance of difference between two groups. Analysis of variance (ANOVA) followed by post hoc analysis by Tukey's honest significant difference was used to assess the significance of difference between more than two groups when data were found to be normally distributed otherwise; $p$-value $<0.05$ was considered to be statistically significant. Statistical Package for the Social Sciences version 14 (IBM Corp., New York, USA) and MS Excel ${ }^{\circledR}$ (Microsoft Corp., New Mexico, USA) were used for statistical calculations.

\section{RESULTS}

The postirrigation optical densities in all the groups were significantly lower in comparison with the preirrigation values when compared with ANOVA for independent samples. Sodium hypochlorite demonstrated better antimicrobial efficacy followed by propolis, neem, and miswak. Differences in optical density using different irrigants were found to be higher in EndoVac $(p<0.0001)$ compared with needle $(\mathrm{p}=0.0009)$ by Student's t-test, but the difference failed to reach statistical significance for all the groups (Table 1).

\section{DISCUSSION}

Root canal infection and/or reinfection occurs mainly due to microorganisms present in the canal system. Enterococcus faecalis is the major cause of secondary infection due to its ability to withstand harsh environment, biofilm formation, and dentinal tubule penetration. ${ }^{14,15}$ Several studies

Table 1: Comparison of optical density pre- and postirrigation using EndoVac and needle

\begin{tabular}{lcll}
\hline \multirow{2}{*}{ Irrigation used } & \multicolumn{2}{c}{ Optical density $($ mean \pm SD) } & \\
\cline { 2 - 3 } & EndoVac & Needle & p-value \\
\hline NaOCl & $0.45 \pm 0.16$ & $0.35 \pm 0.19$ & 0.06 \\
Neem & $0.21 \pm 0.20$ & $0.16 \pm 0.17$ & 0.22 \\
Miswak & $0.13 \pm 0.16$ & $0.09 \pm 0.10$ & 0.16 \\
Propolis & $0.21 \pm 0.16$ & $0.18 \pm 0.20$ & 0.2 \\
p-value & $<0.0001$ & 0.0009 & - \\
\hline
\end{tabular}

have been directed toward searching an effective way to eliminate and/or prevent $E$. faecalis from entering into the root canal space. Enterococcus faecalis may access the root canal system during treatment or between appointments. ${ }^{16}$ So, it is crucial to consider treatment regimens focused at eradicating or preventing the infection of E. faecalis and other microorganisms during each phase. Thus, E. faecalis was tested to assess the antibacterial effect of irrigants.

Instrumentation of the apical portion of root canal to a larger file size will potentiate removal of intracanal microorganisms by reaching unaccessible areas and open the dentinal tubules to allow antimicrobials to penetrate more efficiently. Also, the microcannula of EndoVac has tip diameter of $0.32 \mathrm{~mm}$, so the minimal apical size requirement is selected per se. Preirrigation and postirrigation optical density was measured using digital colorimeter as it indicates the turbidity of test broth in comparison with sterile broth.

The mean values for preirrigation and postirrigation optical density were compared using Student's t-test for all the irrigating solutions. It was found that the mean postirrigation values were significantly reduced than the mean preirrigation values $(\mathrm{p}<0.05)$. So, it can be stated that $E$. faecalis is sensitive to all four irrigants tested in this study, i.e., sodium hypochlorite, neem, miswak, and propolis (Graph 1).

Sodium hypochlorite is a quite effective irrigant for all presentations of E. faecalis including its biofilm form. ${ }^{15}$ Sodium hypochlorite has been found to be significantly better than all the tested herbal irrigants in both EndoVac and needle irrigation group with $0.45 \pm 0.16$ and $0.35 \pm$ 0.19 mean difference in optical density values respectively. This antimicrobial action is because of the high $\mathrm{pH}(>11)$ and presence of $\mathrm{OCl}^{-}$ions (equivalent to hypochlorous acid), which facilitates its penetration into bacterial cell

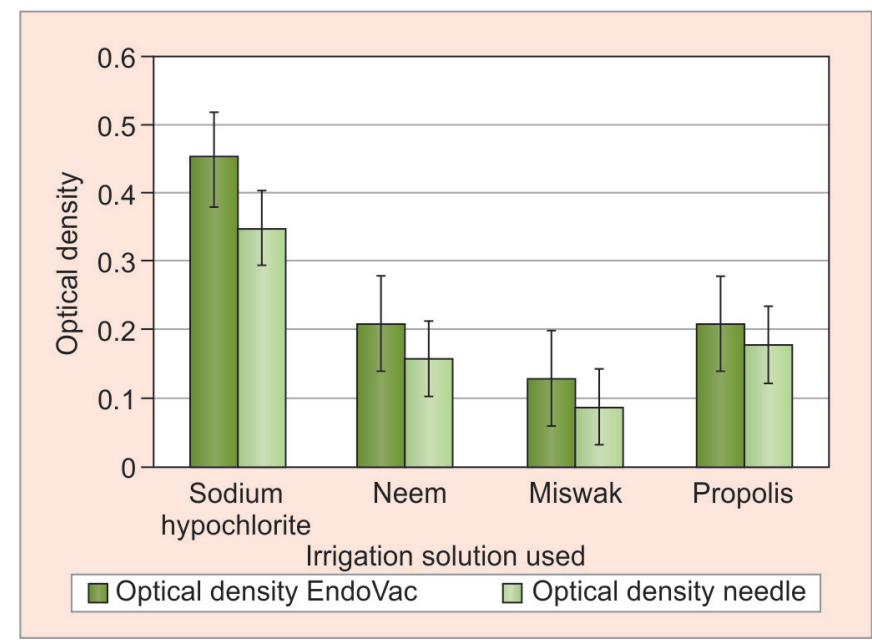

Graph 1: Comparison of optical density pre- and postirrigation using EndoVac and needle 
wall, chemical combination with protoplasm, and disruption of metabolic activities and deoxyribonucleic acid synthesis. ${ }^{4,17}$ The high susceptibility of microorganisms to $\mathrm{NaOCl}$ was verified by several authors. ${ }^{3,4,16-18}$

Among the herbal irrigants, the antibacterial activity in descending order is as follows: Propolis, neem, and miswak, although the results are not statistically significant. For EndoVac and needle irrigation group, the mean reduction in optical density for propolis was $0.21 \pm 0.16$ and $0.18 \pm 0.20$, and for neem $0.21 \pm 0.20$ and $0.16 \pm 0.17$ respectively. The result of this study is in accordance to studies done by Garg et $\mathrm{al}^{2}{ }^{2}$ Bhardwaj et $\mathrm{al}^{19}{ }^{19}$ and Saxena et $\mathrm{al}_{1}^{20}$ who suggested that propolis has strong antimicrobial action against $E$. faecalis next to $\mathrm{NaOCl}$. This effect of propolis is possibly due to the flavonoids and esters of phenolic acids. ${ }^{21}$ But it does not correlate with several other studies of Shingare and Chaugule, ${ }^{1}$ Hedge and Kesaria, ${ }^{22}$ and Mathew et $\mathrm{al}^{23}$ where it has been stated that propolis has minimal antibacterial effect against E. faecalis.

The antimicrobial activity of neem was comparable to propolis and is considered to be due to its antiadherence activity by altering bacterial adhesion and their ability to colonize. ${ }^{7,24}$ Garg et al, ${ }^{2}$ Saxena et $\mathrm{al}_{1}{ }^{20}$ and Radwan et al ${ }^{25}$ stated similarly that neem is less efficacious than $\mathrm{NaOCl}$, whereas this disagrees with the studies by Rosaline et al, Hedge and Kesaria, ${ }^{22}$ Bohora et $\mathrm{al}_{,}{ }^{26}$ Ghonmode et al, ${ }^{27}$ and Damre, ${ }^{28}$ where they have suggested neem to be more efficacious than sodium hypochlorite. Such divergence might be elucidated by critical methodologic differences of the studies.

The mean bacterial reduction by miswak extract was $0.13 \pm 0.16$ and $0.09 \pm 0.10$ in EndoVac and needle groups respectively, and is significantly less than that of $\mathrm{NaOCl}$. Results were in accordance with those of Shingare and Chaugule. ${ }^{1}$

The results also suggest that difference in optical density for all irrigants is higher in EndoVac compared with needle irrigation group, but the difference failed to reach statistical significance (Table 1). This collaborates to studies by Brito et al, ${ }^{29}$ Miller and Baumgartner, ${ }^{30}$ and Miranda et al, ${ }_{1}^{14}$ where EndoVac was found to be better than conventional needle irrigation with no statistically significant antibacterial superiority, but not in accordance to in vitro experiment by Hockett et al, ${ }_{12}$ where EndoVac produced statistically significantly better microbial control than traditional irrigation delivery system. Better results in EndoVac group may be attributed to the apical suction effect of pulling irrigants down and along the walls of the root canal system, which creates vacuum pressure pulling microparticles out of the root canal system through the holes in microcannula by directing irrigants as close as $0.2 \mathrm{~mm}$ from the WL. ${ }^{31}$ During this study, the holes of microcannula were constantly checked to prevent clogging of holes, which may affect the efficacy of irrigation. The clogged holes were made patent with a positive pressure rinse, or the cannula was changed.

\section{CONCLUSION}

Within the limitations of the present study, it can be concluded that:

- Among all medicaments, sodium hypochlorite proved to be a better irrigant than propolis, neem, and miswak.

- Among herbal irrigants, propolis was superior than neem and miswak.

- EndoVac irrigation system was more effective for elimination of E. faecalis than needle irrigation group.

\section{REFERENCES}

1. Shingare $\mathrm{P}$, Chaugule V. Comparative evaluation of antimicrobial activity of miswak, propolis, sodium hypochlorite and saline as root canal irrigants by microbial culturing and quantification in chronically exposed primary teeth. Germs 2011 Dec;1(1):12-21.

2. Garg P, Tyagi SP, Sinha DJ, Singh UP, Malik V, Maccune ER. Comparison of antimicrobial efficacy of propolis, Morinda citrifolia, Azadiracta indica, triphala, green tea polyphenols and $5.25 \%$ sodium hypochlorite against Enterococcus fecalis biofilm. Saudi Endo J 2014 Aug;4(3):122-127.

3. Byström A, Sundqvist G. Bacteriologic evaluation of the effect of 0.5 percent sodium hypochlorite in endodontic therapy. Oral Surg Oral Med Oral Pathol 1983 Mar;55(3):307-312.

4. Gomes BP, Ferraz CC, Vianna ME, Berber VB, Teixeria FB, Souza-Filho FJ. In vitro antimicrobial activity of several concentrations of sodium hypochlorite and chlorhexidine gluconate in the elimination of Enterococcus faecalis. Int Endo J 2001 Sep;34(6):424-428.

5. Grossman LI, Meiman BW. Solution of pulp tissue by chemical agents. J Am Dent Assoc 1941 Feb;28(2):223-225.

6. Prabhakar J, Senthilkumar M, Priya MS, Mahalakshmi K, Sehgal PK, Sukumaran VG. Evaluation of antimicrobial efficacy of herbal alternatives (triphala and green tea polyphenols), MTAD, and 5\% sodium hypochlorite against Enterococcus faecalis biofilm on tooth substrate: an In vitro study. J Endod 2010 Jan;36(1):83-86.

7. Rosaline H, Kandaswamy D, Gogulnath D, Rubin Ml. Influence of various herbal irrigants as a final rinse on the adherence of Enterococcus faecalis by fluorescence confocal laser scanning microscope. J Cons Dent 2013 Jul-Aug;16(4):352-355.

8. Kandaswamy D, Venkateshbabu N, Gogulnath D, Kindo AJ. Dentinal tubule disinfection with $2 \%$ chlorhexidine gel, propolis, Morinda citrifolia juice, $2 \%$ povidone iodine and calcium hydroxide. Int Endod J 2010 May;43(5):419-423.

9. Bazvand L, Aminozarbian MG, Farhad A, Noormohammadi H, Hasheminia SM, Mobasherizadeh S. Antibacterial effect of triantibiotic mixture, chlorhexidine gel, and two natural materials propolis and aloe vera against Enterococcus faecalis: an ex vivo study. Dent Res J (Isfahan) 2014 Jul;11(4):469-474.

10. Saha S, Nair R, Asrani H. Comparative evaluation of propolis, metronidazole with chlorhexidine, calcium hydroxide and 
Curcuma longa extract as intracanal medicament against E. faecalis - an in vitro study. J Clin Diag Res 2015 Nov;9(11): ZC19-ZC21.

11. Nielsen BA, Craig Baumgartner J. Comparison of the EndoVac system to needle irrigation of root canals. J Endod 2007 May;33(5):611-615.

12. Hockett JL, Dommisch JK, Johnson JD, Cohenca N. Antimicrobial efficacy of two irrigation techniques in tapered and nontapered canal preparations: an in vitro study. J Endod 2008 Nov;34(11):1374-1377.

13. Desai $\mathrm{P}$, Himel V. Comparative safety of various intracanal irrigation systems. J Endod 2009 Apr;35(4):545-549.

14. Miranda RG, Santos EB, Souto RM, Gusman H, Colombo APV. Ex vivo antimicrobial efficacy of the Endovac ${ }^{\circledR}$ system plus photodynamic therapy associated with calcium hydroxide against intracanal Enterococcus faecalis. Int Endod J 2012 Nov;46(6):499-505.

15. Stuart CH, Schwartz SA, Beeson TJ, Owatz CB. Enterococcus faecalis: Its role in root canal treatment failure and current concepts in retreatment. J Endod 2006 Feb;32(2):93-98.

16. Berber VB, Gomes BP, Sena NT, Vianna ME, Ferraz CC, Zaia AA, Souza-Filho FJ. Efficacy of various concentrations of $\mathrm{NaOCl}$ and instrumentation techniques in reducing Enterococcus faecalis within root canals and dentinal tubules. Int Endo J 2006 Jan;39(1):10-17.

17. Siqueira JF Jr, Rõças IN, Favieri A, Lima KC. Chemomechanical reduction of the bacterial population in the root canal after instrumentation and irrigation with $1 \%, 2.5 \%$, and $5.25 \%$ sodium hypochlorite. J Endod 2000 Jun;26(6):331-334.

18. Arias-Moliz MT, Ferrer-Luque CM, Espigares-Garcia M, Baca P. Enterococcus faecalis biofilms eradication by root canal irrigants. J Endod 2009 May;35(5):711-714.

19. Bhardwaj A, Velmurugan N, Sumitha, Ballal S. Efficacy of passive ultrasonic irrigation with natural irrigants (MCJ, aloe-vera, and propolis) in comparison with $1 \% \mathrm{NaOCl}$ for removal of E. faecalis biofilm: an in-vitro study. Indian J Dent Res 2013 Jan-Feb;24(1):35-41.

20. Saxena D, Saha SG, Saha MK, Dubey S, Khatri M. An in vitro evaluation of antimicrobial activity of five herbal extracts and comparison of their activity with $2.5 \%$ sodium hypochlorite against Enterococcus faecalis. Indian J Dent Res 2015 Dec;26(5):524-527.
21. Kujumgiev A, Tsvetkova I, Serkedjieva $\mathrm{Y}$, Bankova V, Christov R, Popov S. Antibacterial, antifungal and antiviral activity of propolis of different geographical origin. J Ethanopharmacol 1996 Mar;64(3):235-240.

22. Hedge V, Kesaria DP. Comparative evaluation of antimicrobial activity of neem, propolis, turmeric, liquorice and sodium hypochlorite as root canal irrigants against E. faecalis and C. albicans - an in vitro study. Endod J 2013 Dec;25(2):38-45.

23. Mathew T, Shetty A, Hegde MN. Comparison of antimicrobial activities of Moringa oleifera leaf, propolis, $2 \%$ chlorhexidine gluconate and MTAD on E. faecalis - an in-vitro study. Res J Pharm Bio Chem Sci 2014 May-Jun;5(3):163-173.

24. Kishen A, Sum CP, Mathew S, Lim CT. Influence of irrigation regimens on the adherence of Enterococcus faecalis to root canal dentin. J Endod 2008 Jul;34(7):850-854.

25. Radwan IN, Randa B, Hend AN, Camilia G. Evaluation of antimicrobial efficacy of four medicinal plants extracts used as root canal irrigant on Enterococcus faecalis: an in-vitro study. Int Dent Med J Adv Res 2015 Dec;1:1-8.

26. Bohora A, Hegde V, Kokate S. Comparison of the antibacterial efficiency of neem leaf extract and $2 \%$ sodium hypochlorite against E. faecalis, C. albicans and mixed culture - an in vitro study. Endodontology 2010;22(1):8-12.

27. Ghonmode WN, Balsaraf OD, Tambe VH, Saujanya KP, Patil AK, Kakde DD. Comparison of the antibacterial efficiency of neem leaf extracts, grape seed extracts and 3\% sodium hypochlorite against E. faecalis - an in vitro study. J Int Oral Health 2013 Dec;5(6):61-66.

28. Damre PG. Comparative evaluation of antimicrobial activity of herbal vs chemical root canal irrigants against E. faecalis - an in vitro study. Int J Adv Res 2015 Sep;3(9):1563-1572.

29. Brito PR, Souza LC, Machado de Oliveria JC, Alves FR, DeDeus G, Lopes HP, Siqueira JF Jr. Comparison of the effectiveness of three irrigation techniques in reducing intracanal Enterococcus faecalis populations: an in vitro study. J Endod 2009 Oct;35(10):1422-1427.

30. Miller TA, Baumgartner JC. Comparison of the antimicrobial efficacy of irrigation using the EndoVac to endodontic needle delivery. J Endod 2010 Mar;36(3):509-511.

31. Shin SJ, Jee SW, Song JS, Jung IY, Cha JH, Kim E. Comparison of regrowth of Enterococcus faecalis in dentinal tubules after sealing with gutta-percha or Resilon. J Endod 2008 Apr;34(4):445-448. 